\title{
Assessment of Dairy Marketing in Assosa District, Ethiopia
}

\author{
Amente Negussa Bayata \\ Department of Agricultural Economics, Assosa University, Assosa, Ethiopia \\ Email address: \\ amentnug@gmail.com

\section{To cite this article:} \\ Amente Negussa Bayata. Assessment of Dairy Marketing in Assosa District, Ethiopia. American Journal of Plant Biology. \\ Vol. 5, No. 3, 2020, pp. 60-67. doi: 10.11648/j.ajpb.20200503.15
}

Received: August 21, 2020; Accepted: September 5, 2020; Published: November 23, 2020

\begin{abstract}
The important roles of livestock in the developing countries within the agricultural sector in contributing to rural livelihoods and particularly those of the poor are well recognized. Ethiopia holds large potential for dairy development due to its large livestock population, the favorable climate for improved, high-yielding animal breeds, and the relatively disease-free environment for livestock. This study was initiated to Assessment of Dairy Marketing in Assosa District, Ethiopia. The focus of the study was to identify actors and their roles in dairy marketing chains; and to identify the challenges and opportunities of dairy marketing chains in the study area. The type of data use for assessment is cross sectional data. Different variables were hypothesized to determine dairy marketing. The data was supplemented by primary and secondary sources. Primary survey was conducted in Assosa district to obtain the total number of households that have dairy animals in the three selected kebeles for dairy production. The secondary data is generated from both published and unpublished documents. Descriptive statistics has been used to assess the generated data. The results obtained from this assessment indicate absence of training service and lack of transportation service were found to be the most important significant variables influencing dairy marketing in the district. Therefore, providing training and improving transportation facilities to strengthen the vertical and horizontal linkages among the marketing agents are recommended to develop and strengthen information on dairy marketing in the study area.
\end{abstract}

Keywords: Dairy, Marketing, Assessment, Assosa, Descriptive Statistics

\section{Introduction}

\subsection{Background of the Study}

The important roles of livestock in the developing countries within the agricultural sector in contributing to rural livelihoods and particularly those of the poor are well recognized [1]. Livestock and their products are estimated to make up about a third of the total values of agricultural gross output in the developing countries, and this share is rising from time to time.

Agriculture is the backbone of the Ethiopian economy, that earnings foreign exchange and domestic consumption. However, the highland of Ethiopia is one of the densely populated and poorest regions in the world with per capital income of US\$110 [2].

Livestock production in these countries is increasing rapidly in response to the fast growing demand for livestock products resulting from increasing population especially that of urban areas, and rising consumer income and the sector is found to play an increasing role in peri-urban systems. These systems are driven by growth of urban demand and efficiency of market chains linking more remote producers to these markets and also frequently provide income opportunities for landless poor, who provide fodder, collect waste to feed to animals and engage in distribution and marketing of outputs [3].

Ethiopia holds large potential for dairy development due to its large livestock population, the favorable climate for improved, high-yielding animal breeds, and the relatively disease-free environment for livestock. Given the considerable potential for smallholder income and employment generation from high-value dairy products, development of the dairy sector in Ethiopia can contribute significantly to poverty alleviation and nutrition in the country. Like other sectors of the economy, the dairy sector in Ethiopia has passed through three phases or turning points, following the economic and political policy in the country. In the most recent phase, characterized by the transition towards market-oriented economy, the dairy sector appears to be moving towards a takeoff stage. Liberalized markets and private sector investment and promotion of smallholder dairy 
are the main features of this phase. Milk production during the $1990 \mathrm{~s}$ expanded at an annual rate of 3.0 percent compared to $1.63-1.66$ percent during the preceding three decades. Review of the development of dairy sector in Ethiopia indicates that there is a need to focus interventions more coherently. Development interventions should be aimed at addressing both technological gaps and marketing problems. Integration of crossbred cattle to the sector is imperative for dairy development in the country. This can be achieved either through promotion of large private investment to introduce new technology in the sector such as improved genotypes, feed and processing, and promotion of integration of crossbred cattle into the smallholder sector through improving their access to improved cattle breeds, AI service, veterinary service, and credit. Similarly, government should also take the lead in building infrastructure and providing technical service to smallholders. Severe shortages, low quality and seasonal unavailability of feed likewise remain as major constraints to livestock production in Ethiopia. These constraints need to be addressed and technological change be promoted to increase milk production [4].

Small-scale livestock farmers in the study area benefited from increased access to livestock service of LSPs trained by CLP and other NGOs. It was possible because the farmers were the main producer of milk, supporting them with livestock service was necessary to close gap in value chain growth [5].

Dairying constitutes an important part of the Ethiopian smallholder crop/livestock mixed farming system. The country is known to have the highest number of cattle in Africa, making it one of the biggest potential producers of milk and milk products in the continent. Despite this advantage, the industry is plagued with a number of constraints and the country remains a net importer of milk and milk products. The farmers are poorly organized into cooperatives and unions, while their products are sold at sub optimal prices [6].

Pieces of information are useful in designing appropriate cattle pricing as well as cattle marketing procedures and provision of services like reliable marketing information to avoid unfair cattle-pricing practices. These measures could enhance the efficiency of cattle pricing system and consequently improve the livelihoods of cattle keepers and handlers [7].

Milk is one of most produced and valuable dairy products with a total production of 770 billion litters valued at USD 328 billion, milk ranked third by production tonnage and was the top dairy products in Ethiopia. Milk contributes $27 \%$ to the global value added of livestock and $10 \%$ to that of agriculture. However, dairy marketing is a key constraint to dairy development throughout Ethiopia. Marketing problems must be addressed if dairying is to realize its full potential to provide food and stimulate broad-based agricultural and economic development.

Market supply was significantly affected by quantity of pepper produced; pepper farming experience, one year lagged price and family size [8].

Some milk supply is distributed from producer to consumer through informal way in both rural and urban areas. The informal market involves direct delivery of fresh milk by producers to consumers in the neighborhoods. Facilities and infrastructures of the marketing chains are not fully developed in the country. In turn, reduces incentives to participate in economic transactions and result in subsistence rather than market-oriented dairy production system [9].

\subsection{Statement of the Problem}

Ethiopia is one of the major pastoralists, where large populations of the dairy livestock are found. However, the use of such potential livestock products to be minimal in many areas of the country and poor dairy marketing system pertains to be the main factors contributing to the minimal utilization of available dairy products. Some milk supply is distributed from producer to consumer informally in both rural and urban areas. Facilities and infrastructures of the marketing system are not fully developed in the country. Different levels of access to infrastructure, assets, and information explain why they contemporaneously accept widely different producer prices for fluid milk [10].

Moreover, there is no clear cut information about the existing dairy marketing channels and their roles along the marketing chain. Dairy marketing chain so is supposed to be the current approach working in marketing channels of dairy products problems [11].

An efficient dairy marketing chain is one which enables farmers to receive at least $50 \%$ of the retail price of milk [12].

There are various players (from individuals to institutions) in the dairy sector that play sundry roles at different levels. These include: farm input suppliers, producers of different scales, cooperatives and unions, extension service providers, traders, processors, distributors, industry facilitators, development partners and consumers as end users [13].

No studies have been carried out to analyze dairy marketing chain and no remedial measures were taken so far in selected kebeles of Assosa district. This study was therefore, designed to assess dairy marketing chain and identify factors influencing dairy marketing chain in the study area.

\subsection{Objective of Study}

\subsubsection{General Objective}

The overall objective of the study is to assess dairy marketing chain in Assosa District

\subsubsection{Specific Objectives}

With the above general objective, the study focused the following Specific objectives.

1. To identify actors and their roles in dairy marketing in the study area.

2. To identify the challenges and opportunities of dairy marketing chains in the study area. 


\section{Research Methodology}

\subsection{Description of the Study Area}

This study was under taken in Assosa district of Assosa zone, Benishangul-Gumuz regional state, Ethiopia. It is one of the seven districts found in Assosa zone. It is composed of 74 rural and 1- urban (Selga 22) lower administrative units. It is located about $663 \mathrm{~km}$ to North West Addis Ababa.

The district has total population of about 92,687 of which 45,820 are females, 46,867 are males. About 25\%, 60\% and $15 \%$ of the total population were young, economically active and old age, respectively. Average family sizes for the district is 6 persons per household. Due to Weather condition the district has not produced Dairy as required so that there is no access to marketing agents [14].

The annual rainfall of the district ranges from 219.7 to 1858.3 and range of annual temperature from minimum to maximum $14.7 \mathrm{c}$ to $16.3 \mathrm{c}$ and $26.5 \mathrm{c}$ to $30.1 \mathrm{c}$. The district has altitude of 1300-1570 above sea level. The main rainy season in the district is from April to end September. The economy to the districts mainly dominated by traditional cash crop farming and major crops produced in the district include sesame, groundnut, and sorghum. According the information we received from BGSS this district is the first in producing Dairy than all the seven districts Dairy animals [15].

\subsection{Sample Size and Sampling Techniques}

\subsubsection{Sampling Size and Techniques}

A multi- stage purposive and random sampling techniques was used to identify the district, kebeles, and sample respondents of dairy products. From all the seven districts of Assosa zone, Assosa district was purposively selected at the first stage because of production potential of dairy products. In identification of kebeles; Selga 22, Selga 23 and Selga 24 were selected randomly. About, 122 households were selected from a total population 18,881 of households through random sampling technique because of each household dairy product produce equally. This study was employed descriptive design to collect and assess the desired information from sample households.

Primary survey was conducted in Assosa district to obtain the total number of households that have dairy animals in the three selected kebeles for dairy production.

\subsubsection{Sample Size Determination}

The sample size for this study was determined by using stratified formula by [16], as:

$$
\mathrm{n}=\frac{N}{1+N(e)^{2}}=\frac{18,881}{1+18,881(0.09)^{2}}=122
$$

Where: $\mathrm{n}=$ represents the sample respondents

$\mathrm{N}=$ shows total number of population in the selected keble's.

$\mathrm{e}=$ Level of precision (range in which the true value of the population is estimated to be and it is expressed in percentage points).
Therefore, a total of about 122 sample respondents and other market participants were used for the study.

\subsection{Types and Source of Data}

Both qualitative and quantitative type of data types were used from different data sources. In order to meet purpose of this study, primary and secondary sources were utilized from the sample respondents. Primary data was collected from dairy household, kebele leaders, and development agents. Secondary data included different related works or documents, findings and statistics offices and government organizations of the area which was collected from both published and unpublished materials.

\subsection{Methods of Data Collection}

Primary data was generated from a sample survey that was conducted using household interview schedule, field observation. In addition to this, secondary sources were collected from agricultural and rural development office of the district, administrative office of district, published and unpublished documents.

\subsection{Data Assessment Methods}

Descriptive statistics and inferential statistics of data analysis method were employed for this particular study.

Descriptive statistics was employed for the description of different demographic, socio economic, communication and situational characteristics of the sample respondents. These are mean, percentage, standard deviation and frequency. All the information gathered, concerning dairy marketing was analyzed by using tables, graphs etc.

\section{Results and Discussion}

\subsection{Demographic Characteristics of Sample Households}

The demographic characteristics of the sample respondents are depicted. Of the total sample respondents (122) handled during the survey period, $86.07 \%$ were male-headed households and $13.93 \%$ were female-headed in the study areas (Table 1).

The chi-square test shows the existence of significant statistical differences for extension services on dairy marketing chains of producer households at level of $1 \%$ significance between the three kebeles. This indicates, dairy marketing chain of producers has not better access to extension services.

Similarly, market information is found to be statistically significant at level of $10 \%$ indicating there is a lack of market information during the survey period. Of the total of sample three groups $77.87 \%$ has lacked accessed to market information.

Access to credit is also found to be statistically significant at level of $10 \%$ which indicates there is no access to credit service in the study area. Of the total of sample three groups only about $22.95 \%$ accessed to credit service. The reason for 
the low percentages of respondents who had access to credit service may be because of the high interest rate charged by private lenders. As pointed out from the sample respondents of the study area, even though farmers need credit to purchase different inputs to enhance the quantity dairy products, the short repayment period as well as the high interest rate of the service was not suitable to the individual respondents. At the time of survey it was understood that, the only private institution that deliver credit in the district were OCSI and some private lenders (informal credit).
Farming was the main occupation and source of livelihood for the majority $(82.79 \%)$ of the farmers in the study area. Majority of respondents from the respective Selga 22 have been practicing mixed crop like livestock production, dairying, mango production, sesame production, ground nut production, maize production, wheat production and ...etc. However, in addition to the farming activities, some respondents $(17.21 \%)$ have also engaged in off-farm activities like in small trading activities (table 1).

Table 1. Demographic characteristics of the sample respondents (dummy variables).

\begin{tabular}{|c|c|c|c|c|c|c|c|c|c|c|}
\hline \multirow{2}{*}{ Characteristics } & \multirow{2}{*}{ Item } & \multicolumn{2}{|c|}{ Selga 24} & \multicolumn{2}{|c|}{ Selga 23} & \multicolumn{2}{|c|}{ Selga 24} & \multicolumn{2}{|c|}{ Total } & \multirow{2}{*}{$\chi^{2}$-test } \\
\hline & & $\mathbf{N}$ & $\%$ & $\mathbf{N}$ & $\%$ & $\mathbf{N}$ & $\%$ & $\mathbf{N}$ & $\%$ & \\
\hline \multirow{2}{*}{ Sex } & Male & 39 & 86.67 & 39 & 82.98 & 27 & 90 & 105 & 86.07 & \multirow{2}{*}{0.77} \\
\hline & Female & 6 & 13.33 & 8 & 17.02 & 3 & 10 & 17 & 13.93 & \\
\hline \multirow{2}{*}{ Training on production } & Yes & 15 & 33.33 & 19 & 40.43 & 8 & 26.67 & 42 & 34.43 & \multirow{2}{*}{1.57} \\
\hline & No & 30 & 67.67 & 28 & 59.57 & 22 & 73.33 & 80 & 65.57 & \\
\hline Ext. service & No & 24 & 53.33 & 43 & 91.49 & 26 & 87.67 & 93 & 76.23 & $20.86^{* * *}$ \\
\hline \multirow{2}{*}{ Mkt. info. } & Yes & 15 & 33.33 & 8 & 17.02 & 4 & 13.33 & 27 & 22.13 & \multirow{2}{*}{$5.34 * *$} \\
\hline & No & 30 & 67.67 & 39 & 82.92 & 26 & 86.67 & 95 & 77.87 & \\
\hline \multirow{2}{*}{ Access to credit } & Yes & 13 & 28.89 & 11 & 23.4 & 4 & 13.33 & 28 & 22.95 & \multirow{2}{*}{2.47} \\
\hline & No & 32 & 71.11 & 36 & 76.6 & 24 & 86.67 & 94 & 77.05 & \\
\hline Member of cooperatives & Yes & 6 & 13.33 & 4 & 8.51 & 3 & 10 & 13 & 10.66 & 0.58 \\
\hline \multirow{2}{*}{ Off farm activities } & Yes & 3 & 6.67 & 7 & 14.89 & 11 & 36.67 & 21 & 17.21 & \multirow{2}{*}{$0.003 * * *$} \\
\hline & No & 42 & 93.33 & 40 & 85.11 & 19 & 63.33 & 101 & 82.79 & \\
\hline
\end{tabular}

$* * *$ and $* * *$ indicates significant at $1 \%, 5 \%$ and $10 \%$ level of significance respectively, Ext.=extension, Mkt. info.=Market information

Source: Survey result, 2016

Regarding the educational status of the sample respondents about $44.44 \%$ were illiterate, while a greater majority $(45.9 \%)$ of them can read and write. The other respondents attended from elementary to secondary school. More specifically, $11.48 \%$ and $7.38 \%$ of the sample respondents had attended elementary and secondary schools respectively. The rest of the respondents completed their education level from higher school. Further, about $4.92 \%$ and $0.82 \%$ of the respondents completed their diploma and degree respectively. On the basis of marital status, most of the household heads surveyed $(87.7 \%)$ were married with only 0.82 percent divorced household head and $5.74 \%$ single equal to widow (table 2 ).

Table 2. Demographic characteristics of sample respondents (continuous variables).

\begin{tabular}{|c|c|c|c|c|c|c|c|c|c|}
\hline \multirow{2}{*}{ Variables } & \multirow{2}{*}{ Items } & \multicolumn{2}{|c|}{ Selga 22} & \multicolumn{2}{|c|}{ Selga 23} & \multicolumn{2}{|c|}{ Selga 24} & \multicolumn{2}{|c|}{ Total } \\
\hline & & $\mathbf{N}$ & $\%$ & $\mathbf{N}$ & $\%$ & $\mathbf{N}$ & $\%$ & $\mathbf{N}$ & $\%$ \\
\hline \multirow{6}{*}{ Education } & Illiterate & 20 & 44.44 & 4 & 8.51 & 6 & 20 & 30 & 29.51 \\
\hline & Read \& write & 22 & 48.89 & 16 & 34.04 & 8 & 26.67 & 46 & 45.90 \\
\hline & Elementary & 0 & 0 & 15 & 31.91 & 0 & 0 & 15 & 11.48 \\
\hline & Secondary school & 0 & 0 & 8 & 17.02 & 0 & 0 & 8 & 7.38 \\
\hline & College (Dip) & 0 & 0 & 3 & 6.39 & 14 & 46.67 & 17 & 0.82 \\
\hline & Degree level & 3 & 6.67 & 1 & 2.13 & 2 & 6.66 & 6 & 4.92 \\
\hline \multirow{3}{*}{ Marital Status } & Married & 40 & 88.89 & 42 & 89.36 & 25 & 83.3 & 107 & 87.7 \\
\hline & Divorced & 0 & 0 & 0 & 0 & 1 & 3.36 & 1 & 0.82 \\
\hline & Widowed & 2 & 4.44 & 3 & 6.38 & 2 & 6.67 & 7 & 5.74 \\
\hline
\end{tabular}

Source: Survey result, 2016.

\subsubsection{Characteristics of Households (Continuous Variables)}

Average household heads age was 42.77 for Selga 22, 44.94 for Selga 23, and 40.87 for Selga 24, years, respectively. The overall mean age of the sampled respondents was 43.14 years with $10 \%$ level of significance among marketing channel choice of producers. This implies that those dairy producer households who sell their dairy products to local processors were found to be more old age relating to the farmers selling dairy products to consumers. 
The average family size of the total sample respondents was found to be 5.27, 5.12 and 5.98 persons in Selga 22, Selga 23 and Selga 24, respectively. The overall family size member of the sample respondents was 5.45. The average years of farming experience related to dairy production was 12.2, 13.55 and 12.97 years in Selga 22, Selga 23 and Selga 24 , respectively.

The overall average years of dairy products farming experience was 13.12 years. There was significant difference in dairy production experience in the three kebeles at $1 \%$ significant level which indicates the more dairy farming experience prefers processors agents. The $t$-test also showed that the variable family size is statistically significance at $1 \%$ significant level indicating a high number of family sizes depend on income from dairy production (Table 3 ).

Table 3. Demographic characteristics of samples (continuous variables).

\begin{tabular}{lllllllll}
\hline \multirow{2}{*}{ Variables } & Selga 22 & & Selga 23 & Selga 24 & \multicolumn{2}{c}{ Total } \\
\cline { 2 - 8 } & Mean & SD & Mean & SD & Mean & SD & Mean & SD \\
\hline Age & 42.78 & 14.22 & 45.36 & 15.78 & 40.87 & 13.8 & 43.3 \\
Family size & 5.27 & 2.25 & 5.12 & 2.52 & 5.98 & 3.56 & 5.45 & 1.22 \\
Experience & 12.2 & 4.27 & 13.55 & 12.56 & 12.97 & 12.99 & 13.12 & $4.63 * * *$ \\
\hline
\end{tabular}

*** means significant at $1 \%$ level of significance.

Source: Own computation from Survey result, 2016.

\subsubsection{Means of Livelihood}

The respondents depend on different means of income generation strategies where mango and dairy productions were sources of income for the majority of the producers. About $31.97 \%$ of the respondents earned their living from dairy production as a source of income generation. Similarly, Moreover, $4.29 \%$ of the respondents participate in combination of all.

Table 4. Major means of income generation of the respondents in the study districts.

\begin{tabular}{lll}
\hline Major means of income generation & Frequency & Percent \\
\hline Mango production & 41 & 33.61 \\
Dairy production & 39 & 31.97 \\
Mango trading & 15 & 12.30 \\
Dairy trading & 13 & 10.66 \\
Others & 8 & 6.56 \\
Combination of all & 6 & 4.92 \\
Total & 122 & 100 \\
\hline
\end{tabular}

Source: Own computation from Survey result, 2016.

\subsection{Actors and their Roles in Dairy Marketing Chains}

Though good volume and quality of dairy products is produced unless it is sold properly, the farmers may not be benefited.

Producers/farmers: Producers are small scale farmers and they sell their dairy products to different buyers or participants of dairy products market. As the survey results show farmers sell their products to final consumers and dairy products processors. According to the sample respondents, in the production year $2014 / 15$, producers sold about $18.03 \%$ of their dairy products to consumers. The other purchasers $(81.97 \%)$ were other purposes.

Retailers: Retailers are the participants involved in the selling of dairy products to final consumers. There are few retailers who divide large-amount of dairy products and sell it to consumers in small units. These are the final agents in the channel that delivered dairy products to end users. The majority of retailers found at the district center, having their own retail shops.

Processors: This actor's purchase the dairy products directly from farmers for resell to consumers by processing and converting the product to another form like milk, butter, etc. They are fragmented participants but they play significant role in collecting and supplying dairy products to the market.

Consumers: They are the end users of dairy products through purchasing from different marketing agents. In the study area, dairy products consumed in two ways i.e. milk products consumption and butter products consumption. As discussed above, $18.03 \%$ of dairy products sold to the final consumers.

\subsection{Marketing Costs, Benefit Shared Margin of Dairy Marketing Chain Actors}

\subsubsection{Marketing Costs and Benefit Shares of Actors}

The important points to be considered in market chain analysis are marketing costs (cost for value located on the product at different level by market actors along channels), margin, number of intermediaries and share of producers as well as intermediaries from consumers' price or end buyers for dairy products. So as to investigate the shares and margins of several market agents, who are involved in dairy products market chain, different channels starting from farm gates to consumer for local markets price are considered.

Because selling and purchasing process is undertaken by local unit of measurement, before going to margin analysis, determining share of producers and other intermediaries it is important to use a standard conversion factor. Accordingly a full cup, traditionally used material to measure dairy products product in the study areas, is estimated to be equivalent to $6.03 \mathrm{~kg}$. Based on this assumption, margins were calculated for the main actors like producers, processors and retailers. 
Table 5. Dairy products marketing costs and benefit shares of actors per $\mathrm{kg}$.

\begin{tabular}{|c|c|c|c|c|c|}
\hline Cost type & & Producer & Processers & Retailer & Sum \\
\hline Dairy products purchase price & - & - & 50.20896 & 55.21061 & 105.4196 \\
\hline \multirow[t]{6}{*}{ Production cost (A) } & Feed cost & 13.33002 & - & - & 13.33002 \\
\hline & Labor cost & 3.069652 & - & - & 3.069652 \\
\hline & Tax & 0.248756 & - & - & 0.248756 \\
\hline & Transport cost & - & - & - & - \\
\hline & Sum (A) & 16.64842 & - & - & 16.64842 \\
\hline & Labor cost & 0.829187 & 1.121061 & 1.121061 & 3.07131 \\
\hline \multirow{4}{*}{ Marketing cost (B) } & Tax & - & 0.248756 & 0.248756 & 0.49751 \\
\hline & Transport cost & 1.144279 & 1.144279 & 1.495854 & 3.784411 \\
\hline & Sum (B) & 1.973466 & 2.514096 & 2.865671 & 7.353231 \\
\hline & Container & 1.121061 & - & - & 1.121061 \\
\hline \multirow[t]{2}{*}{ Material cost (C) } & Milk container & 0.890547 & 0.890547 & 0.890547 & 1.781095 \\
\hline & Sum (C) & 2.011608 & 0.890547 & 0.890547 & 3.792702 \\
\hline Rent of shop (D) & & - & - & 0.379768 & 0.379768 \\
\hline Other costs $(E)$ & & 0.097844 & 0.097844 & 0.127695 & 0.323383 \\
\hline TOTAL COST (F) & $\mathrm{F}=\mathrm{A}+\mathrm{B}+\mathrm{C}+\mathrm{D}+\mathrm{E}$ & 20.73134 & 3.502487 & 4.263681 & 28.49751 \\
\hline$\%$ share of TC & & 72.7479 & 12.2905 & 14.96159 & 100 \\
\hline Gross sells (Average) & & 55.21061 & 55.21061 & 60.21061 & 170.6318 \\
\hline Marketing margin & & 38.56219 & 5.00165 & 5 & 48.56384 \\
\hline$\%$ share of margin & & 79.40515 & 10.29912 & 10.29573 & 100 \\
\hline Profit margin & & 34.47927 & 1.499163 & 0.736319 & 36.71475 \\
\hline$\%$ share of profit & & 93.91122 & 4.083272 & 2.005513 & 100 \\
\hline
\end{tabular}

Source: Own computation, 2015.

\subsubsection{Marketing Margin}

TGMM( market channel)

$$
\begin{gathered}
=\frac{\text { Price paid by end buyers }- \text { Producers price }}{\text { Consumers Price }} \times 100 \\
=8.31 \%
\end{gathered}
$$

GMM (processors)

$$
\begin{gathered}
=\frac{\text { Price paid by retailers }- \text { Producers price }}{\text { Consumers Price }} \times 100 \\
=4.08 \%
\end{gathered}
$$$$
\text { GMM (retailers) }
$$$$
=\frac{\text { Price paid by consumers }- \text { Price paid by collectors }}{\text { Consumers Price }} \times 100
$$$$
=2.00 \%
$$

GMMp (producers participation $)=100 \%-6.08 \%$

$$
=93.92 \%
$$

Even though, farmers total expense is greater than three fourth (i.e. $79.40 \%$ ) compared to traders $(20.60 \%)$ processors and retailers, their profit margin is also more than nine tenth $(93.92 \%)$ of that traders. That means the farmers were more profitable by selling their dairy products compared to other chai actors. This may be due to transportation and other costs like house rents. Also the input supply farmers used were less compared to dairy products purchasing price traders paid. Traders, bearing all the risks (loss), took only $6.08 \%$ of the profit margin. This disproportionate share of benefits is the reflection of power relationship among farmers. Further, producers added $93.92 \%$ of the total value of dairy products in the study area. Processors and retailers are responsible for $4.08 \%$ and $2.00 \%$, respectively.

\subsection{Opportunities and Constraints of Dairying in the Study Area}

\subsubsection{Opportunities of Dairy Products}

The dairy products sector is one of the few sectors that had the most inclusive ability to achieve transformation and growth across all categories of rural households through increasing the income of the rural people. The availability of natural forest and the wide plantation of mango production make Assosa district as one of the homes for foraging bee colonies. Therefore, these opportunities create favorable condition for this sub sector in the district. The details about the opportunities forwarded by the respondents are presented in the table 6.

Table 6. Opportunities of dairying in the study area.

\begin{tabular}{lll}
\hline Variables & Frequency & Percent \\
\hline Availabilities of natural forests & 67 & 54.92 \\
Mango plantation & 34 & 27.87 \\
Availability of water resource & 21 & 17.21 \\
Total & 122 & 100 \\
\hline
\end{tabular}

Source: Survey result, 2016.

As the result obtained from the respondents, $54.92 \%$ of the respondents prioritize the availability of natural forest as major opportunity of the sector. Next to availabilities of natural forests, mango plantation of the area is the second opportunity of the sector that is of $27.87 \%$. Availability of water resource is last prioritized opportunity by the respondents and it takes the share of $17.21 \%$ of the total opportunities (table 6). 


\subsubsection{Constraints of Dairying}

Even though, the study area has a lot of opportunities to the production of dairy products this potential does not used effectively due to different adversely affecting factors.

Table 7. Constraints of Dairying in the study area.

\begin{tabular}{lll}
\hline Identified constraints & Frequency & Percent \\
\hline Lack of milk container & 42 & 34.43 \\
Absence of training service & 31 & 25.41 \\
Lack of transportation service & 24 & 19.67 \\
Inadequacy of credit service & 16 & 13.11 \\
Partiality of the product & 9 & 7.38 \\
Total & 122 & 100 \\
\hline
\end{tabular}

Source: Survey result, 2016

\subsection{Marketing Opportunities and Constraints of Dairying in the study Area}

\subsubsection{Marketing Opportunities of Dairying in the Study Area}

There are many opportunities of dairy market in the study area. Increasing demand for dairy products is one of the opportunities as explained by the Agriculture Bureau officials and sample respondents during the interview. Dairy farmers also agreed that they should have to do together to increase the demand for dairy products by selling the product anywhere as the users wish and communicating with the final users. Table 8 shows the detail about the opportunities of marketing which is prioritized by the sample farmers.

Table 8. Marketing opportunities of dairy products in the study area.

\begin{tabular}{lll}
\hline Identified opportunities & Frequency & Percentage \\
\hline Increasing demand for Dairy product & 65 & 53.3 \\
Communication facilities with purchasers & 30 & 24.6 \\
Selling the product anywhere as users wish & 27 & 21.1 \\
Total & 122 & 100 \\
\hline
\end{tabular}

Source: Survey result, 2016.

As forwarded by $65 \%$ of the respondents increasing demand for dairy products was the first opportunity of dairy products market in the study area. Another opportunity as the respondents forwarded was communication facilities with purchasers $(30 \%)$ to sell their product anywhere as users wish $(27 \%)$.

\subsubsection{Marketing Constraints of Dairying in the Study Area}

When the farmer sets about marketing his product, he faces many constraints. Overcoming them will helps in restoring his self-confidence, and will help him to develop. The primary condition is the general infrastructure, which includes insufficient means of transportation, bad roads, and undeveloped markets. There are no agreed standard rates and measures, and in most places the scales used are biased to the detriment of the farmer. The next factor is the means of storage. Insufficient storage space and faulty facilities give rise to losses. The lack of storage facilities prevents the farmer from keeping his produce until the season when its price rises, resulting in loss of income.

Table 9. Marketing Constraints of Dairy Products.

\begin{tabular}{lll}
\hline Identified constraints & Frequency & Percentage \\
\hline No organized body to purchase dairy & 70 & 54.7 \\
products & 35 & 28.7 \\
Lack of transportation services & 17 & 13.9 \\
Low price of the product & 122 & 100 \\
Total & \\
\hline
\end{tabular}

Source: Survey result, 2016.

Most of the producers $(70 \%)$ claim that the no organized body to purchase dairy product. According to the data collected from officers of Agriculture and Rural Development Bureau of the District, there is no any farmer's cooperative to link their product to the national market.
Mainly at the harvesting time farmers cannot get adequate demand for their product. The second and problem is lack of transportation services $(35 \%)$ for supply of processed dairy products to the market. Farmers prefer some small and simple machines to process their product but there is no access to purchase these machines. The third and last constraint raised by respondents was price offered to their product $(17 \%)$ was unfair and low and this causes decrease in the amount of produce and the number of producers in the study area.

\section{Conclusions and Recommendations}

\subsection{Conclusions}

Farmers of Assosa district have the indigenous practices of dairy production. The factors absence of training service and lack of transportation service affects dairy marketing affects dairy marketing in the study area. Therefore, taking actions that can minimize the identified bottlenecking factors affecting dairy marketing in the study area is necessary.

\subsection{Recommendations}

Based on the findings of the study, the following recommendations are forwarded.

1. It was found that lack of training in production of dairy products in the study area. This problem tends to narrow the marketing of dairy producers. The marketing department should play vital role in giving training to production of dairy product in the study area.

2. The study revealed that lack of infrastructure thereby distances of the market from farmers influence the market outlet choices of producers. Therefore, government and other concerned bodies are recommended to improve basic 
infrastructure for farmers so that they can take their dairy product to the market through available transport services.

\section{References}

[1] Abdur Rob, 2010. Market system for milk and dairy products - Bogra / Sirajgonj chars.

[2] ADARDO (Assosa District Agriculture and Rural Development Office), 2012. District Annual Report of Benishangul Gumuz Regional State, Ethiopia 2012.

[3] FAO/TCP/KEN/6611 Project: Milk and Milk Products Marketing: Training Programme for Small Scale Dairy Sector and Dairy Training Institute - Naivasha.

[4] Gujarati, D. N., 2003. Basic Econometrics. 4th Edition. McGraw-Hill, New York. 563-636p.

[5] Halloway, G. C., C. Nichlson, C. Delgado, S. Staal and S. Ehui, 2000. How to make milk market: A case study from Ethiopian high lands. Socio-econo mics and Policy Research Working Paper 28. ILRI, Nairobi, Kenya. 85p.

[6] Holloway, G., and S. Ehui, 2002. Expanding market participation among smallholder livestock producers: A collection of studies employing Gibbs sampling and data from the Ethiopian highlands.

[7] ILRI, 2005. A collaborative research and development project by Kenya Ministry of Livestock Development, the Kenia Agricultural research institute and the international livestock research institute, Kenya.
[8] ILRI, 2005-2007. Medium-Term Plan. Livestock: A pathway out of poverty.

[9] Islam, M. S., Miah, T. H. and Haque, M. M., 2001. Marketing system of marine fish in Bangladish. Bangladish J. of Agric. Economics. 24 (2): 127-142p.

[10] Lemma et al., 2008; Yilma et al., 201: A Review of the Ethiopian Dairy Sector. FAO Sub Regional Office for Eastern Africa (FAO/SFE. September, 2011.

[11] Mohamed, A. M., Ahmed, Simeon Ehui and Yemesrach Assefa, 2004. Dairy development in Pomeroy, R. S., 1989. The economics of production and marketing in small-scale fishery.

[12] Redda, T., 2001. Small-scale milk marketing and processing in Ethiopia. In Proceedings of South-South Workshop on Smallholder Dairy and Marketing Constraints and Opportunities. March 12-16. Anand, India.

[13] Solomon Tilahun, 2004. Performance of Cattle Marketing System in Southern Ethiopia with special emphasis on BorenaZone. M. Sc. thesis presented to Haramaya University. Haramaya, Ethiopia. 65-67p.

[14] Staal, S. J., 1995. Peri-urban dairying and public policy in Ethiopia and Kenya: A comparativeThe role of livestock in economic development and poverty reduction. Pro-Poor Livestock Policy Initiative. Working Paper 10.

[15] Yamane (1967) A Simplified Formula: For Proportions size provides a simplified formula to calculate sample sizes.

[16] Zelalem Yilma, Emmannuelle Guernebleich and Ameha Sebsibe, 2011. A Review of the Ethiopian Dairy Sector. 